This item was submitted to Loughborough's Research Repository by the author.

Items in Figshare are protected by copyright, with all rights reserved, unless otherwise indicated.

\title{
Pushing climate change science to the roof of the world
}

PLEASE CITE THE PUBLISHED VERSION

https://doi.org/10.1016/j.oneear.2020.10.021

PUBLISHER

Cell Press

VERSION

AM (Accepted Manuscript)

PUBLISHER STATEMENT

This paper was accepted for publication in the journal One Earth and the definitive published version is available at https://doi.org/10.1016/j.oneear.2020.10.021.

\section{LICENCE}

CC BY-NC-ND 4.0

\section{REPOSITORY RECORD}

Mayewski, PA, AP Gajurel, S Elvin, P Athans, T Dinley, P Sherpa, AC Elmore, et al.. 2020. "Pushing Climate Change Science to the Roof of the World". Loughborough University.

https://hdl.handle.net/2134/13691380.v1. 


\section{Pushing Climate Change Science to the Roof of the World}

Authors: Paul Andrew Mayewski ${ }^{1 *}$, Ananta P. Gajurel ${ }^{2}$, Sandra Elvin ${ }^{3}$, Pete Athans ${ }^{4}$, Tyler Dinley $^{5}$, Panuru Sherpa ${ }^{6}$, Aurora C. Elmore ${ }^{7}$, Jiban Ghimire ${ }^{8}$, L. Baker Perry ${ }^{9}$, Tom Matthews ${ }^{10}$, Conrad Anker ${ }^{11}$, Samuel W. Guilford ${ }^{12}$, Mary S. Hubbard ${ }^{13}$, Aaron E. Putnam ${ }^{14}$, Tracie A. Seimon $^{15}$, Anton Seimon ${ }^{16}$, Suresh Ghimire ${ }^{17}$, and Alexander M. Tait ${ }^{18}$

${ }^{1}$ Expedition Leader and Science Leader ${ }^{\text {a }}$, Climate Change Institute, University of Maine, Orono, Maine, USA

${ }^{2}$ Nepal Science Leader and Geology Team Co-Leader a, Department of Geology, Tribhuvan University, Kathmandu, Nepal

${ }^{3}$ Director, NGS Expeditions ${ }^{a}$, National Geographic Society, Washington, DC, USA

${ }^{4}$ Climbing Leader a, North Face, USA; Khumbu Climbing Center, Phortse, Nepal

${ }^{5}$ Producer ${ }^{a}$, National Geographic Society, Washington, DC, USA

${ }^{6}$ Sherpa Team Leader ${ }^{a}$, Xtreme Climbers Ltd., Khumbu Climbing Center, Phortse, Nepal

${ }^{7}$ Senior Program Manager a, National Geographic Society, Washington, DC, USA

${ }^{8}$ Shangri-La Nepal Trek Pvt. Ltd., Kathmandu, Nepal

${ }^{9}$ Meteorology Team Co-Leader a , Department of Geography and Planning and RIEEE, Appalachian State University, Boone, NC, USA

${ }^{10}$ Meteorology Team Co-Leader ${ }^{\text {a }}$, Department of Geography and Environment, Loughborough University, Loughborough, UK

${ }^{11}$ Climbing consultant a, North Face, Khumbu Climbing Center, Phortse, Nepal

12 National Geographic Society, Washington, DC, USA

${ }^{13}$ Geology Team Co-Leader a, Department of Earth Sciences, Montana State University, USA

${ }^{14}$ Geology Team Co-Leader ${ }^{\text {a }}$, Climate Change Institute, University of Maine, Orono, Maine, USA

${ }^{15}$ Biology Team Co-Leader ${ }^{a}$, Wildlife Conservation Society, Zoological Health Program, Bronx Zoo, USA

${ }^{16}$ Biology Team Co-Leader ${ }^{\text {a }}$, Department of Geography and Planning and RIEEE, Appalachian State University, Boone, NC, USA

${ }^{17}$ Biology Team Co-Leader a, Department of Biology, Tribhuvan University, Kathmandu, Nepal

${ }^{18}$ Mapping Team Leader ${ }^{\text {a }}$, National Geographic Society, Washington, DC, USA

a role during 2019 Everest Expedition

"Correspondence: paul.mayewski@maine.edu

The National Geographic and Rolex Perpetual Planet Everest Expedition, hereafter the 2019 Everest Expedition, is a multidisciplinary (biology, geology, glaciology, mapping, meteorology) project dedicated to understanding climate change, climate change impacts, improving climate predictions and providing a framework for future research in mountain environments.

\section{Introduction}

The Hindu Kush Himalaya $(\mathrm{HKH})$ contain the highest mountains on Earth including the highest of all $(8848 m(29,029))$ and it has three names. In Nepal they call it Sagarmatha - "Head (sometimes red head) of the Earth in the Sky" as named by the Nepalese historian Baburam Acharya. In the Tibet Autonomous Region of China it is called Qomolungma - "Mother Goddess 
of the Universe". In the west it is called Mt. Everest after the Surveyor General of India (1865). Mt. Everest is truly iconic and as such it might be assumed that basic scientific questions would already be largely answered.

As explored in this issue of One Earth there is still much to learn about Mt. Everest and mountain systems, in general ${ }^{1,2}$. Glacierized mountains store and provide water for $>22 \%$ of the world's population and $50 \%$ of its biodiversity ${ }^{3}$. As a consequence of climate change and human activity these environments have been changing notably in recent decades and will continue to do so in the future. Information that contributes to understanding current and projecting future: changes in temperature, precipitation, winds, glacier extent and volume, water availability, air and water quality, species abundance and distribution; and risks ${ }^{4}$ associated with climate change, increasing population and resource utilization are essential to the people and ecosystems impacted, 250 million in the Himalayas alone, and to the world at large.

The 2019 Everest Expedition was undertaken in April-May during the pre-monsoon season within the elevation range 3200 to 8430 masl $^{5}$. Figure 1 highlights the wide range of expedition sampling types and their locations in the Khumbu region. Figure 2 highlights the major activities (geology, glaciology, mapping, meteorology, biology) with interdisciplinary examples and scientific findings as summarized below.

\section{Geology - past environmental change}

The investigation of past environments provides perspective for assessing modern and predicting future change through analogues. Therefore, the geology team examined past changes in climate as expressed by glacial moraines and deposits from modern and ancient lakes spanning from tens of thousands of years ago to the last hundreds of years. The approach combined high-resolution drone photography, cosmogenic dating of moraines, coring of two high-elevation glacial lakes, and dating of lake deposits. Analysis of ancient lake deposits stranded on valley walls suggests the strong role that landslides have played in shaping the landscape of this region. The first ever lake cores taken in the Gokyo valley show sediment disturbance and changes in tree species consistent with warming.

The geology team benefitted from partnerships with the mapping team by facilitating the spatial display of analytical results and the connection to local landforms; with the glaciology team in developing records of past change; with the meteorology team in constraining models for past glacier extent; and with the biology team it will provide a survey of diatoms and pollen species.

\section{Glaciology - air/water quality and past climate}

Glaciers contain records of past physical and chemical climate and as glaciers melt they release entrapped chemistry derived from both natural and human sources. Therefore, the glaciology team recovered water and snow samples along the access route to Everest Base Camp and up through the climbing route $(4400-8440 \mathrm{~m})$, from stream samples, and a 32-day continuous series near base camp that includes a major storm event (Cyclone Fani). The team also recovered ice cores from the Khumbu Glacier near Base Camp and the highest ice core ever collected at $8020 \mathrm{~m}$ from the South Col of Mt. Everest (recovered by glaciology team member Mariusz Potocki and the Sherpa team).

Sample analysis include: 49 major and trace elements, stable isotopes of water, polyfluoroalkyl substances, biological material, plastics and radiocarbon dating. Both atmospherically deposited and direct contact humanly deposited pollution was found at several sites along the climbing route and near a village used as a trekking logistics base. It is clear that human activity has left 
a mark in local snow and ice in the form of toxic metals, plastic fibers ${ }^{6}$, pesticides, plasticizers, and waterproof gear coatings.

The glaciology team is partnering with several universities and all of the 2019 Everest disciplines to enhance data interpretation by comparing water/snow/ice results with the meteorology and geology teams to provide past perspective for assessing modern and predicting future climate. Past precipitation, atmospheric circulation and atmospheric chemistry determined from an ice core recovered at $6518 \mathrm{~m}$ on the north side of Mt. Everest ${ }^{7}$ will be used to compare to the South Col ice core results to understand local climate and glacier volume change gradients. Glacier ablation studies including black carbon and dust sampling will aid in determining past, modern and future glacier dynamics being modeled by the mapping team. Biological sampling of the ice cores will be compared to modern environment sampling by the biology team.

\section{Mapping - spatial and temporal context}

Maps provide the basis upon which scientific data can be placed to assess spatial distribution and, in the process, provide a basis for assessing change. The mapping team completed LiDAR (optical sensing) and photographic surveys of the Everest Base Camp area $(5300 \mathrm{~m})$, at 1-2 centimeter resolution, and over the full extent of the Khumbu Glacier from the base of the Lhotse face to the toe of the glacier, at 5-10 centimeter resolution. The set of geographic data includes elevation models (from lidar point cloud and photogrammetric processing), visible imagery, and infrared imagery. The team produced the highest helicopter LiDAR scanning in the world, the first LiDAR scan of the highest glacier in the world, and the first complete LiDAR and photographic survey of Everest Base Camp.

The mapping team is working closely with the other members of the 2019 Everest Expedition to integrate their data into their high-resolution map products. Examples include: the geology team is using relief shading and other geomorphological renderings of the lateral and terminal moraines in its analysis of the glacial history of the Khumbu region; and the biology team is using mapping team color-infrared imagery to determine distribution and as a basis for assessing changes in vegetation. In addition, elevation, glacier surface and mass balance ${ }^{8}$ descriptions and changes feed into analyses by both the meteorology and glaciology teams.

\section{Meteorology - essential ground-based observations}

Ground-based weather stations provide calibration for model interpretations of weather and climate and site-specific weather for local forecasting. Therefore, the meteorology team installed five automatic weather stations (AWS), including the two highest in the world ${ }^{9}$, gathered observations of a snowstorm from the world's highest vertically pointing radar deployment at Base Camp ${ }^{10}$; identified moisture sources for the precipitation arriving in the region ${ }^{11}$; and provided a detailed case study of weather during the 2019 pre-monsoon period ${ }^{12}$. Results contribute towards improved understanding of future water availability, and the connections between Everest's weather and larger scale atmospheric circulation.

The first paper emerging from the 2019 Everest Expedition ${ }^{9}$ demonstrates that insolation on Everest is intense enough to drive glacier surface melting at elevations above $8,000 \mathrm{~m}$, despite air temperatures well below $0^{\circ} \mathrm{C}$. Latent heat release from cloud formation is shown to warm the atmosphere at altitudes up to Everest summit which helps constrain the vertical gradients in temperature and precipitation required for distributed glacier mass balance modelling. Along with an assessment of oxygen availability ${ }^{13}$ at the summit another team product finds that winds on the upper mountain reflect those in the free atmosphere. This research paves the way for improved forecasting of winds that may be dangerous to climbers. 
Providing context for interpreting the world's highest ice core is a key synergy between the meteorology and glaciology teams. Establishing the contemporary climatology is similarly relevant for the biology and geology teams, and the mapping team benefits from AWS data collected during the expedition to correct drone, helicopter, and satellite datasets for atmospheric interference.

\section{Biology - species abundance and distribution}

High elevation regions lack the species abundance and distribution data available in most lower reaches of the planet, therefore, the biology team performed environmental DNA analysis of ponds and streams between 4,500-5,500 masl. Results demonstrate the diversity of high-alpine organisms present including viruses, bacteria, unicellular organisms, plants, fungi, invertebrates and vertebrates, and differences in community structure both within and among various watersheds. This dataset can be utilized for biomonitoring, species identification, and for tracking changes as climate driven warming, glacier recession and human influences rapidly reshape this globally important landscape ${ }^{14}$.

The Nepalese botany team established the first long-term vegetation monitoring plots in the Upper Khumbu as part of the Global Observation Initiative in Alpine Environments (GLORIA) network ${ }^{15}$. These plots will enable researchers to monitor changes in plant species distribution including introduction or upward expansion of known or invasive species, and changes in plant community structure over time to inform how climate warming is impacting high-alpine plant biodiversity.

Interdisciplinary investigations include the biology team partnering with the mapping team to apply machine learning and artificial intelligence to high-resolution imagery to assess elevation and landscape distribution of plants. The geology team's landscape history reconstructions will inform characterizations of the individual watersheds where the biology team sampled resident life forms, and the meteorology team will provide descriptions of the bioclimatic envelopes within which species reside. In addition, the eDNA database provides a reference dataset and library of organisms currently residing in the Khumbu above 4,500m that can be compared to fossil pollen, plant and microbial remains in the lake sediment and ice core samples obtained during the expedition.

\section{Conclusion}

Mountain systems are changing at a rapid rate with significant consequences for humans and ecosystems. Understanding the current and predicting the future state of mountain systems is essential, but collecting the necessary information is non-trivial, particularly from the highest reaches of the planet. The results presented in this issue and many to follow will allow the 2019 Everest Expedition to leave its legacy for future research in the $\mathrm{HKH}$ and worldwide throughout mountainous regions. The expedition's legacy is based on its multi- and interdisciplinary approach and the scientific framework it set in place that includes: (1) high resolution imagery of the Khumbu Glacier and proximal surroundings to assess change and as a basis for innovative identification of ground-based features; (2) a suite of automatic weather stations that extend into the upper troposphere that can sense stratospheric incursions, and allow testing of weather models while also improving safety for climbers; (3) biological monitoring networks that provide a basis for assessing plant species adaptation to climate change; (4) an eDNA reference database that can be used to assess species distribution or compare to fossil pollens, diatoms, plant and microbial remains; (5) a water/snow sampling network for assessing changes in water quality; (6) past climate change perspective based on ice core, lake sediment and surface age 
exposure mapping; and (7) identification of emerging atmospheric, biological, geological and health risks on Mt. Everest and the Khumbu Valley.

\section{ACKNOWLEDGEMENTS}

2019 Everest Expedition research was conducted through a partnership with National Geographic Society, Rolex, and Tribhuvan University with approval from all relevant agencies of the Government of Nepal (Department of Hydrology and Meteorology, Ministry of Energy, Water Resources and Irrigation, Department of National Parks and Wildlife Conservation, Ministry of Forest and Environment, Ministry of Culture, Tourism and Civil Aviation, Survey Department). We wish to thank Shangri-La Nepal Trek, Xtreme Climbers Treks and Expedition P. Ltd, the US Embassy American Club, Fisher Creative and Virtual Wonders for all of their support. Many thanks to the National Geographic project staff (Kyler Abernathy, Alexis Bahl, Valerie Craig, Aurora Elmore, Sam Guilford, Fae Jencks, Elena Studier). Listed by alphabetically by field team the 2019 Everest Expedition included: biology (Ashish Dami, Kajol Basukala, Roshan BC, Ashish Dami, Suresh Ghimire, Suman Poudel, Anton Seimon, Tracie Seimon, Manisha Timalsina), geology (Bhuwan Awasthi, Samir Dhungel, Ananta Gajurel, Anil Ghimire, Bibek Giri, Mary Hubbard, Laura Mattis, Aaron Putnam, Bal Krishna Shrestha, Lal Bahadur Thapa Singjali, Peter Strand), glaciology (Heather Clifford, Inka Koch, Paul Mayewski, Mariusz Potocki, Tenzing Chogyal Sherpa, Praveen Kumar Singh), mapping (Kenny Broad, Corey Jaskloski, Chris Milbern, Alex Tait), meteorology (Arbindra Khadka,Tom Matthews, Baker Perry), logistics (Pete Athans, Sandra Elvin), Sherpa and Nepali climbers (Panuru Sherpa, Phu Tashi Sherpa, Pemba Sherpa, Urken Lendu Sherpa, Ila Nuru Sherpa, Fura Chetten Sherpa, Lakpa Gyaljen Sherpa, Pasang Sona Sherpa, Pasang Kami Sherpa, Nima Rita Sherpa, Tenzing Gyanjen Sherpa, and Nawang Phinjo Sherpa, Dawa Yangzum Sherpa, Amrit Ale), and storytelling (Katja Adolphson, Dirk Collins, Eric Daft, Tyler Dinley, Fredrik Edstrom, Martin Edstrom, Mark Fisher, Brittany Mumma, Sam Sheline, Emil Wesolowski, Freddie Wilkinson) and all of the porters, people and businesses in the Khumbu Valley who made our journey successful and most pleasurable. We would also like to thank all of the labs, universities, and institutions who are analysing samples and data collected by the 2019 Everest Expedition, only a portion of which is presented in this issue.

\section{Author Contributions}

Conceptualization P.A.M.; Investigation P.A.M., A.P.G., L.B.P., T.M., M.S.H., A.E.P., T.E.S., A.S., S.G., A.M.T..; Writing - Original Draft, P.A.M., L.B.P., T.M., M.S.H., A.E.P., T.E.S., A.S., S.G., A.M.T.,; Writing - Editing, P.A.M., A.P.G., S.E., P.A., T.D., P.S., A.E., J.G., L.B.P., T.M., C.A., M.S.H., A.E.P., T.E.S., A.M.T., S.G., A.M.T.; Visualization, S.W.G.; Planning, A.C.E., S.E., A.M.T., P.A.M., C.A., P.A.

\section{Declaration of Interests}

The authors declare no conflict of interest.

\section{Funding:}

This work was supported by National Geographic Society and Rolex. 


\section{REFERENCES}

1. Mayewski, P.A., Perry, L. B., Matthews, T. and Birkel, S. (2020). Climate change in the Himalayas: Basis and gaps. One Earth, 3. XXX-XXX.

2. Elmore, A.C., N. Alexiev, V. Craig (2020). Understanding the World's Water Towers Through High Mountain Expeditions and Scientific Discovery. One Earth. 3, XXX-XXX.

3. Immerzeel, W.W., Lutz, A.F., Andrade, M., Bahl, A., Blemans, H., Bolch, T., Hyde, S., Brumby, S., Davies, B.J., Elmore, A.C., Emmer, A., Feng, M., Fernandez, A., Haritashya, U., Kargel, J.S., Koppes, M., Kraaijenbrink, P.D.A., Kulkarni, A.V., Mayewski, P.A., Nepal, S., Pacheco, P., Painter, T.H., Pellicciotti, F., Rajaram, H., Rupper, S., Sinisalo, A., Shrestha, A.B., Viviroli, D., Wada, Y., Xiao, C., Yao, T. and Baille, J. (2019). Importance and vulnerability of the world's water towers, Nature. https://doi.org/10.1038/s41586-019-1822-y.

4. Miner, K.R., Mayewski, P.A., Baidya, S.K., Clifford, H., Gajurel, A., Bibek, G., Hubbard, M., Koldewey, H., Li, W., Matthews, T., Napper, I., Perry, B., Potocki, M., Priscu, J. Tait, A., Thompson, R. and Tuladhar, S. (2020). An overview of physical risks in the Mt. Everest region. One Earth. 3, XXX-XXX.

5. Elvin, S., P. Athans, P.A. Mayewski, J. Ghimire, A.C. Elmore, V. Craig. (2020). Behind the scenes of a comprehensive scientific expedition to Mt. Everest. One Earth. 3, XXXXXX.

6. Napper, I.E., B.F.R. Davies, H. Clifford, S. Elvin, H. Koldeway, P.A. Mayweski, K.R. Miner, M. Potocki, A.C. Elmore, A.P. Gajurel, and R.C. Thompson. (2020). Reaching new heights in plastic pollution - preliminary findings of microplastics on Mount Everest. One Earth. 3, XXX-XXX.

7. Kaspari, S., Mayewski, P.A., Kang, S., Sneed, S., Kreutz, K., Introne, D., Hooke, R., Maasch, K., Qin, D., Ren, J. (2007). Reduction in northward incursions of the South Asian Monsoon since 1400 A.D. inferred from a Mt. Everest ice core, Geophys. Res. Letts., 34, doi:10.1029/2007GL030440.

8. King, O., Bhattacharya, A., Tait, A., Guilford, S., Elmore, A.C., and Bolch, T. (2020). Six decades of glacier mass changes around Mt. Everest revealed by historical and contemporary images. One Earth. 3, XXX-XXX.

9. Matthews, T., Perry, L.B., Koch, I., Aryal, D., Khadka, A., Shrestha, D., Abernathy, K., Elmore, A.C., Seimon, A., Tait, A., Elvin, S., Tuladhar, S., Baidya, S.K., Potocki, M., Birkel, S.D., Kang, S., Mayewski, P.A. (2020). Going to extremes: installing the world's highest weather stations on Mount Everest. Bull. Amer. Meteor. Soc., doi: https://doi.org/10.1175/BAMS-D-19-0198.1.

10. Perry, L.B., Yuter, S.E., Matthews, T., Wagnon, P., Khadka, A., Aryal, D., Shrestha, D., Tait, A., Miller, M.A., O’Neill, A., Rhodes, S.R., Koch, I., Sherpa, T.G., Tuladhar, S., Baidya, S.K., Elvin, S., Elmore, A.C., Gajurel, A., Mayewski, P.A. (2020). Direct observations of a Mount Everest Snowstorm from the World's Highest Surface-Based Radar Observations. Weather, In Press.

11. Perry, L.B., Matthews, T., Guy, H., Koch, I., Khadka, A., Elmore, A.C., Shrestha, D., Tuladhur, S., Baidya, S.K., Maharjan, S., Wagnon, P., Aryal, D., Seimon, A., Gajurel, A., and Mayewski, P.A. (2020b). Precipitation Characteristics and Moisture Source Regions on Mt. Everest in the Khumbu, Nepal. One Earth. 3, XXX-XXX.

12. Khadka, A., Matthews, T., Perry, L.B., Koch, I., Wagnon, P., Shrestha, D., Aryal, D., Tait, A., Sherpa, T.G., Tuladhar, S., Baidya, S.K., Elvin, S., Elmore, A.C., Gajurel, A., and Mayewski, P.A. (2020). Weather at Mt. Everest during the 2019 summer monsoon. Weather. In press.

13. Matthews, T., Perry, B., Lane, T.P., Elmore, A.C., Shrestha, D., Tuladhar, S., Baidya, S.K., Aryal, D., Gajurel, A. and Mayewski, P.A. (2020b). Into Thick(er) Air? Oxygen Availability at Humans' Physiological Frontier on Mount Everest. iScience. In press. 
14. Pauli, H., and Halloy, S.R.P. (2019). High Mountain Ecosystems Under Climate Change, Oxford Res. Encycl. Clim. Sci., 1-56.

15. GLORIA (Global Observation Initiative in Alpine Environments network (https://gloria.ac.at/network/general).

\section{Figures}

Figure 1 - Sampling locations.

Sample types and locations for the full region covered by 2019 Everest Expedition (A) and a blow-up for Everest Base Camp to Everest Summit (B).

Figure 2 - Interdisciplinarity and world records.

2019 Everest Expedition scientific disciplines (with institutions involved in field sampling and/or analyses), sub-disciplines and interdisciplinary interactions. DHM: Department of Hydrology and Meteorology, Nepal; BU: Brown University, USA; CWU: Central Washington University, USA; ICIMOD, Nepal; MSU: Montana State University, USA; PSI: Paul Scherrer Institute, Switz.; UM: University of Maine, USA; NGS: National Geographic Society, USA; WCS: Wildlife Conservation Society, USA; VW: Virtual Wonders, USA; TU: Tribhuvan University, Nepal; SA: University of St. Andrews, UK; ASU: Appalachian State University, USA; LU: Loughborough University, UK; NCSU: North Carolina State University, USA; UL: University of Leeds, UK; PU: Purdue University, USA; GA: Grenoble-Alpes University, France. 